\title{
Sensory and ATP derivative-based indicators for assessing the freshness of Atlantic salmon (Salmo salar) and cod (Gadus morhua)
}

Colin Fogarty ${ }^{1,2}$, Conor Smyth ${ }^{1,3}$, Paul Whyte $^{2}$, Nigel Brunton ${ }^{3}$, Declan Bolton ${ }^{1 \dagger}$

${ }^{1}$ Teagasc Food Research Centre, Ashtown, Dublin 15, Ireland

${ }^{2}$ School of Veterinary Medicine, University College Dublin, Belfield, Dublin 4, Ireland

${ }^{3}$ School of Agriculture and Food Science, University College Dublin, Belfield, Dublin 4, Ireland

Abstract

To estimate the shelf life of fresh fish, the processor must know the period of time between catch/harvest and arrival at the processing plant. This information is not always available, necessitating the provision of methods to estimate the time since catch or harvest. The objectives of this study were therefore to develop and/or validate sensory and ATP derivative-based methods for rapidly assessing the freshness of fish. A quality index method (QIM; raw fish) and a quantitative descriptive analysis (QDA; cooked fish) were developed and validated (against bacterial count [total viable count (TVC)] and time) for salmon (Salmo salar) and cod (Gadus morhua). The production of inosine monophosphate (IMP), inosine and hypoxanthine ( $H x)$ and associated ratios (IMP/Hx, $K_{1}$-value or $H$-value) were also investigated for use as freshness markers. There was a linear relationship between QIM and TVC $\left(R^{2}=0.93\right.$ for salmon and $R^{2}=0.89$ for cod), QIM and time $\left(R^{2}=0.96\right.$ for salmon and $R^{2}=0.98$ for cod), $Q D A$ and TVC $\left(R^{2}=0.93\right.$ for salmon and $R^{2}=0.77$ for cod) and $Q D A$ and time $\left(R^{2}=0.94\right.$ for salmon and $R^{2}=0.87$ for cod), suggesting that the QIM and QDA schemes developed could be used to monitor/assess freshness. The $H$-value also increased linearly with $T V C\left(R^{2}=0.88\right.$ for salmon and $R^{2}$ $=0.89$ for cod $)$ and time $\left(R^{2}=0.93\right.$ for salmon and $R^{2}=0.84$ for cod). It was therefore concluded that both the QIM/QDA approach and monitoring ATP degradation, specifically expressed as the $H$-value, could be used as rapid methods to assess the freshness of salmon and cod arriving at the processing plant.

Keywords

Atlantic cod (Gadus morhua) • Atlantic salmon (Salmo salar) • ATP derivatives • quality index method

- quantitative descriptive analysis

\section{Introduction}

Fresh seafood is perishable with a short shelf life (Ghanbari et al., 2013) and approximately $10 \%$ is lost due to spoilage each year (Kulawik et al., 2013; Alfaro et al., 2013). Chemical and enzymic autolytic processes commence immediately following death, resulting in the loss of the 'fresh' flavours of fish. Unpleasant odours and tastes are then produced by the metabolic activities of spoilage bacteria (Schirmer et al., 2009; Mørkøre et al., 2010). Thus, spoilage is a complex process involving enzymatic, chemical and microbiological changes, but the latter is the primary determinant of shelf life (Anacleto et al., 2011).

The quality index method (QIM) is a scheme used to assess the freshness of fish based on scoring different sensory attributes (appearance, odour and texture) during storage (Bremner, 1985). Assuming the quality index (QI) increases linearly with time, once the total score for fish at the end of their shelf life is established, the score obtained prior to this can be used to estimate the remaining shelf life (Martinsdóttir et al., 2001). A similar approach, quantitative descriptive analysis (QDA), is used to assess the sensory status of cooked fish and is often combined with the QIM assessment of the raw product by seafood specialists to achieve additional assurance of the quality of the fish (Sveinsdottir et al., 2002). Although QIM schemes have been previously developed for several fish species including pollock, plaice, haddock, turbot, dab, salmon, herring, cod and mackerel (Bonilla et al., 2007; Jónsdóttir, 1992; Andrade et al., 1997; Luten, 2000), more detailed schemes that use language relevant to the Irish fish processors are required (personal communication). Moreover, QDA to assess the sensory status of cooked fish is currently not available.

The autolytic processes that commence immediately postmortem include the deamination of adenosine phosphate molecules (ATP, ADP and AMP) to inosine monophosphate (IMP) before being more slowly dephosphorylated to inosine (I) and eventually degraded to hypoxanthine $(\mathrm{Hx}$; Gram and Dalgaard, 2002; Chen et al., 2010). The concentration of I and $\mathrm{Hx}$, expressed as the IMP/Hx ratio or the modified $K_{1}$-value $[(\mathrm{I}+$ $\mathrm{Hx}) /(\mathrm{IMP}+\mathrm{I}+\mathrm{Hx}) \times 100]$ or the $H$-value $[\mathrm{Hx} /(\mathrm{IMP}+\mathrm{I}+\mathrm{Hx}) \times 100]$,

\footnotetext{
†Corresponding author: Declan J. Bolton

E-mail: declan.bolton@teagasc.ie
} 
has been proposed as indicators of freshness for fish, but their formation varies greatly depending on the fish species and storage conditions. Several studies have demonstrated a linear relationship between $\mathrm{Hx}$ concentration and time in a range of fish species (Beauchat, 1973; Jahns and Rand, 1977; Dingle and Hines, 1971; Jones et al., 1964; Kassemsarn et al., 1963). However, a number of alternative studies have concluded that IMP (Dingle and Hines, 1971; Ehira and Uchiyama, 1974) or I (Bremner et al., 1988; Murata and Sakaguchi, 1988) are better biochemical markers for evaluating freshness, although the concentrations obtained are not always linear over time (Beauchat, 1973; Jahns and Rand, 1977; Murata and Sakaguchi, 1988; Bremner et al., 1988). Research is, therefore, required to determine which, if any, of these indices are suitable for use in assessing the freshness of salmon (Salmo salar) and cod (Gadus morhua). The objectives of this study were to develop and validate rapid sensory (QIM and QDA) and ATP derivative-based methods for assessing the freshness of salmon and cod arriving at the processing plant.

\section{Materials and methods}

\section{Fish samples}

Whole fresh Atlantic salmon and cod were obtained within 48 and $24 \mathrm{~h}$ of harvest or capture, respectively, from Connolly Fish Sales (Rathmines, Dublin 6, Ireland). The salmon and cod were of a consistent size (3-4 kg and 2.5-3 kg, respectively). The fish were transported on ice to the laboratory (Teagasc Food Research Centre, Ashtown, Dublin 15, Ireland) within $1 \mathrm{~h}$. Once on site, both the salmon and cod were stored on ice in polystyrene boxes at $2^{\circ} \mathrm{C}$, for up to10 days.

\section{Sensory analysis}

A QIM was developed for scoring attributes of the whole fish and raw fillets for both salmon (Table 1) and cod (Table 2). The fish were graded by a trained panel of 12 people, all from the Teagasc Food Research Centre (Ashtown, Dublin, Ireland). The panel underwent two 1.5-h training sessions, where they became familiar with different terminologies and descriptive language for the grading scheme. From these sessions, it was apparent what attributes needed to be included in the QIM grading scheme, i.e. skin colour, eyes, gills, texture, stiffness and mucus (whole fish) and flesh colour, odour, texture, stiffness and mucus (raw fillet). The QIM grading of the fish samples was carried out on days $0,2,3,6,8$ and 10. On each of these days, the panel was presented with a whole fish and a raw fillet. There were descriptions for each attribute that related to a score of $0,1,2$ or 3 (with the lower score indicating a fresher sample), and each panellist graded the fish by indicating which description they thought best described the physical attribute.

QDA was carried out alongside the QIM to score the characteristics of cooked salmon (Table 3) and cod (Table 4). Similar to the QIM grading scheme, panellists were asked to grade the sensory attributes (colour, odour, taste, mouth-feel, juiciness) of the cooked fish on a scale ranging from 0 to 2 , where a lower score indicated a fresher sample. Samples were steam cooked at $99^{\circ} \mathrm{C}$ for $7 \mathrm{~min}$ (Rational SCC WE 61E Electric Combi Oven, Rational, Landsberg am Lech, Germany), after which the panellists assessed the cooked fillet. Each panellist was given a small piece of cooked fish and asked to grade it. As with the QIM, a scoring sheet was provided with descriptions relating to a score of 0,1 or 2 for each physical attribute. All panellists graded the fish by indicating which description they thought best described the physical attribute. Each QIM score was scored out of 33, and each QDA was scored out of 12 . These scores were then converted to a percentage, which was used as the freshness score.

\section{ATP derivative analysis}

ATP degradation was measured on days $0,2,3,6,8$ and 10. On each day, two flesh samples $(5 \mathrm{~g})$ were aseptically removed from the whole fish. The degradation of ATP was measured using a microplate PRECICE ${ }^{\circledR}$ K-Freshness Assay Kit following the manufacturer's methodology (Novocib, Lyon, France). This kit measures the progressive conversion of IMP, I and $\mathrm{Hx}$ to $\mathrm{NADH}_{2}$, using specific dehydrogenase enzymes provided in the kit. The $\mathrm{NADH}_{2}$ is then quantified by measuring specific absorbance at $340 \mathrm{~nm}$ (Multiskan GO, Thermo Fisher Scientific, Dublin, Ireland) in accordance with the manufacturer's instructions. The concentration of I and $\mathrm{Hx}$ was expressed as the IMP/Hx ratio or the modified $K_{1}$-value $[\mathrm{I}+\mathrm{Hx} /(\mathrm{IMP}+\mathrm{I}+\mathrm{Hx}) \times 100]$ or the $H$-value [Hx/(IMP $+(+H x) \times 100]$.

\section{Microbiological analysis}

Microbiological analysis was carried out on days $0,2,3,6$, 8 and 10. On each sampling day, the fish was split into two sides. From one side, there were two samples $(10 \mathrm{~g})$ of inner flesh obtained on each sampling day. From the other side, the outer skin of the fish was swabbed $\left(25 \mathrm{~cm}^{2}\right.$ surface areas) in duplicate using sterile cellulose acetate sponges pre-moistened with maximum recovery diluent [MRD; Oxoid, Basingstoke, United Kingdom (CM0733)]. Each of the meat and skin swab samples was homogenised (Pulsifier Ò PUL100E; Microgen Bioproducts Ltd, Surrey, United Kingdom) for $1 \mathrm{~min}$ in $90 \mathrm{~mL}$ MRD, and 10-fold dilution series was prepared up to $10^{-5}$. Plate count agar [PCA; Oxoid, Basingstoke, United Kingdom (CM0325)], with and without $1 \% \mathrm{NaCl}$, was used to estimate the total viable count (TVC; $30^{\circ} \mathrm{C}$ for $72 \mathrm{~h}$ ). 
Table 1. Quality index method (QIM) scheme used to evaluate the sensory characteristics of salmon (Salmo salar) stored at $2^{\circ} \mathrm{C}$ for 10 days

\begin{tabular}{|c|c|c|}
\hline Parameter & Description & Score \\
\hline \multicolumn{3}{|c|}{ QIM - whole salmon } \\
\hline \multirow[t]{3}{*}{ Skin colour } & Shiny, bright without blemishes, iridescent pigmentation, silver & 0 \\
\hline & Rather dull & 1 \\
\hline & Dull, slimy, gritty, grey, lack of pigmentation & 2 \\
\hline \multirow[t]{3}{*}{ Mucus (gills) } & Uniform, thin, transparent & 0 \\
\hline & Little thicker, opaque & 1 \\
\hline & Clotted, thick, yellowish & 2 \\
\hline \multirow[t]{3}{*}{ Slime (body) } & Transparent, white & 0 \\
\hline & Off-white & 1 \\
\hline & Yellowish, grey-brown & 2 \\
\hline \multirow[t]{2}{*}{ Eye } & Bright, full, clear & 0 \\
\hline & Cloudy, dull, sunken & 1 \\
\hline \multirow[t]{3}{*}{ Stiffness } & Firm & 0 \\
\hline & Not quite firm & 1 \\
\hline & Soft & 2 \\
\hline \multirow[t]{3}{*}{ Texture } & Quick rebound from finger pressure & 0 \\
\hline & Slow response to finger pressure & 1 \\
\hline & Persistence of finger imprint & 2 \\
\hline \multirow[t]{3}{*}{ Back } & Firm, full, unblemished & 0 \\
\hline & Slightly soft & 1 \\
\hline & Soft, mushy, blemishing, sunken & 2 \\
\hline \multirow[t]{3}{*}{ Belly } & Firm, full, unblemished, intact & 0 \\
\hline & Slightly soft & 1 \\
\hline & Faded, sunken, bruised, battered, grazed & 2 \\
\hline \multirow[t]{3}{*}{ Blood } & Bright red, not present & 0 \\
\hline & Dull red & 1 \\
\hline & Shadowy, brown & 2 \\
\hline \multirow[t]{2}{*}{ Gills } & Bright red, full & 0 \\
\hline & Brown, shrivelled & 1 \\
\hline \multicolumn{3}{|c|}{ QIM - salmon fillets } \\
\hline \multirow[t]{3}{*}{ Colour } & Orange, bright & 0 \\
\hline & Some white, pale & 1 \\
\hline & Overall pale & 2 \\
\hline \multirow[t]{3}{*}{ Texture } & Firm & 0 \\
\hline & Rather soft & 1 \\
\hline & Very soft & 2 \\
\hline \multirow[t]{3}{*}{ Brightness } & Transparent, bluish & 0 \\
\hline & Opaque & 1 \\
\hline & Milky & 2 \\
\hline \multirow[t]{4}{*}{ Odour } & Fresh, neutral & 0 \\
\hline & Seaweedy, marine, grass & 1 \\
\hline & Sour milk & 2 \\
\hline & Acetic, ammonia, offensive, unpleasant & 3 \\
\hline \multirow[t]{2}{*}{ Stiffness } & Rigour & 0 \\
\hline & Post rigour & 1 \\
\hline \multirow[t]{3}{*}{ Mucus } & Absent & 0 \\
\hline & Some evidence & 1 \\
\hline & Excessive & 2 \\
\hline \multirow[t]{4}{*}{ Gaping } & No gaping, one longitudinal gaping at the neck part of the fillet & 0 \\
\hline & Slight gaping, less that $25 \%$ of the fillet & 1 \\
\hline & Slight gaping, $25 \%-75 \%$ of the fillet & 2 \\
\hline & Deep gaping or slight gaping, more than $75 \%$ of the fillet & 3 \\
\hline
\end{tabular}


Table 2. Quality index method (QIM) scheme used to evaluate the sensory characteristics of cod (Gadus morhua) stored at $2^{\circ} \mathrm{C}$ for 10 days

\begin{tabular}{|c|c|c|}
\hline Parameter & Description & Score \\
\hline \multicolumn{3}{|c|}{ QIM - whole cod } \\
\hline \multirow[t]{3}{*}{ Skin colour } & Shiny, bright without blemishes, iridescent pigmentation, silver & 0 \\
\hline & Rather dull & 1 \\
\hline & Dull, slimy, gritty, grey, lack of pigmentation & 2 \\
\hline \multirow[t]{3}{*}{ Mucus (gills) } & Uniform, thin, transparent & 0 \\
\hline & Little thicker, opaque & 1 \\
\hline & Clotted, thick, yellowish & 2 \\
\hline \multirow[t]{3}{*}{ Slime (body) } & Transparent, white & 0 \\
\hline & Off-white & 1 \\
\hline & Yellowish, grey-brown & 2 \\
\hline \multirow[t]{2}{*}{ Eye } & Bright, full, clear & 0 \\
\hline & Cloudy, dull, sunken & 1 \\
\hline \multirow[t]{3}{*}{ Stiffness } & Firm & 0 \\
\hline & Not quite firm & 1 \\
\hline & Soft & 2 \\
\hline \multirow[t]{3}{*}{ Texture } & Quick rebound from finger pressure & 0 \\
\hline & Slow response to finger pressure & 1 \\
\hline & Persistence of finger imprint & 2 \\
\hline \multirow[t]{3}{*}{ Back } & Firm, full, unblemished & 0 \\
\hline & Slightly soft & 1 \\
\hline & Soft, mushy, blemishing, sunken & 2 \\
\hline \multirow[t]{3}{*}{ Belly } & Firm, full, unblemished, intact & 0 \\
\hline & Slightly soft & 1 \\
\hline & Faded, sunken, bruised, battered, grazed & 2 \\
\hline \multirow[t]{3}{*}{ Blood } & Bright red, not present & 0 \\
\hline & Dull red & 1 \\
\hline & Shadowy, brown & 2 \\
\hline \multirow[t]{2}{*}{ Gills } & Bright red, full & 0 \\
\hline & Brown, shrivelled & 1 \\
\hline \multicolumn{3}{|c|}{ QIM - cod fillets } \\
\hline \multirow[t]{3}{*}{ Colour } & White, greyish & 0 \\
\hline & Some yellow, a little pinkish & 1 \\
\hline & Yellow or overall pink & 2 \\
\hline \multirow[t]{3}{*}{ Texture } & Firm & 0 \\
\hline & Rather soft & 1 \\
\hline & Very soft & 2 \\
\hline \multirow[t]{3}{*}{ Brightness } & Transparent, bluish & 0 \\
\hline & Opaque & 1 \\
\hline & Milky & 2 \\
\hline \multirow[t]{4}{*}{ Odour } & Fresh, neutral & 0 \\
\hline & Seaweed, marine, grass & 1 \\
\hline & Sour milk & 2 \\
\hline & Acetic, ammonia, offensive, unpleasant & 3 \\
\hline \multirow[t]{2}{*}{ Stiffness } & Rigour & 0 \\
\hline & Post rigour & 1 \\
\hline \multirow[t]{3}{*}{ Mucus } & Absent & 0 \\
\hline & Some evidence & 1 \\
\hline & Excessive & 2 \\
\hline \multirow[t]{4}{*}{ Gaping } & No gaping, one longitudinal gaping at the neck of the fillet & 0 \\
\hline & Slight gaping, less than $25 \%$ of the fillet & 1 \\
\hline & Slight gaping, $25 \%-75 \%$ of the fillet & 2 \\
\hline & Deep gaping or slight gaping, more than $75 \%$ of the fillet & 3 \\
\hline
\end{tabular}


Table 3. Quantitative descriptive analysis (QDA) scheme used to evaluate the sensory characteristics of cooked salmon (Salmo salar)

\begin{tabular}{lll}
\hline Parameter & Description & Score \\
\hline QDA - cooked salmon & \\
Colour & Orange, bright & 0 \\
& Orange, some off-white & 1 \\
& Pale, dull & 2 \\
Odour & Fresh, seaweed odour & 0 \\
& Stronger, fishy & 1 \\
& Strong fishy, offensive, unpleasant & 2 \\
Taste & Mild, fishy, pleasant & 0 \\
& Moderately fishy & 1 \\
Mouthfeel & Strong fishy, offensive, unpleasant & 2 \\
& Dissolve, melt in the mouth, crumbly, soft & 0 \\
& Slightly chewy & 1 \\
Moist & Chewy, rubbery, tough & 2 \\
& Moist, pleasant & 0 \\
& Mildly moist & 1 \\
& Dry, very dry & 2 \\
& Does not stick to or coat the palate or the teeth & 0 \\
& Somewhat sticky & 1 \\
& Coats the palate and teeth & 2 \\
& & \\
& &
\end{tabular}

Table 4. Quantitative descriptive analysis (QDA) scheme used to evaluate the sensory characteristics of cooked cod (Gadus morhua)

\begin{tabular}{lll}
\hline Parameter & Description & Score \\
\hline \multicolumn{2}{l}{ QDA - cooked cod } & \\
Colour & White, bright & 0 \\
& Off-white & 1 \\
& Dull, dark & 2 \\
Odour & Fresh, seaweed odour & 0 \\
& Stronger fishy & 1 \\
& Strong fishy, offensive, unpleasant & 2 \\
Taste & Mild, fishy, pleasant & 0 \\
& Moderately fishy & 1 \\
& Strong fishy, offensive, unpleasant & 2 \\
Mouthfeel & Dissolve, melt in the mouth, crumbly, soft & 0 \\
& Slightly chewy & 1 \\
& Chewy, rubbery, tough & 2 \\
Moist & Moist, pleasant & 0 \\
& Mildly moist & 1 \\
& Dry, very dry & 2 \\
Sticky/gluey & Does not stick to or coat the palate or the teeth & 0 \\
& Somewhat sticky & 1 \\
& Coats the palate and teeth & 2 \\
\hline
\end{tabular}

\section{Temperature analysis}

EL-USB-2 temperature data loggers (Lascar Electronics, Whiteparish, United Kingdom) recorded the ambient temperature of the storage cold room environment, while a Testo 175T3 data logger (Testo, Lenzkirch, Germany) was used to record skin and core temperatures of the whole salmon and cod.

\section{Data analysis}

The sensory analysis (QIM and QDA) was carried out as described earlier at times $t=0,2,3,6,8$ and 10. At the same time intervals, the ATP derivative analysis was performed using two samples from the same fish and the TVC was obtained using four samples (two inner flesh samples and two outer skin swab samples) from the same fish. This constituted one trial, which was then repeated twice more. The equation of best fit and the correlation coefficients $(R)$ of QIM and QDA against TVC (flesh and skin swab), storage time in ice, IMP concentration (mg/g), Hx concentration $(\mathrm{mg} / \mathrm{g})$, I concentration (mg/g), the IMP/Hx ratio, the $K_{1}$-value (\%) and the $H$-value $\left(\% \mathrm{Hx}\right.$ ) were calculated using Microsoft ${ }^{\circledR}$ Excel 2010 (Microsoft Corporation, Redmond, WA, USA).

\section{Results}

Over the 10 days storage on ice in a chilled room set at $2^{\circ} \mathrm{C}$, the average ambient temperature recorded was $1.6^{\circ} \mathrm{C}$ $\left( \pm 0.8^{\circ} \mathrm{C}\right)$. The average skin and core temperatures for salmon ranged between $1.5^{\circ} \mathrm{C}( \pm 0.9)$ and $2^{\circ} \mathrm{C}( \pm 0.8)$, whereas the average skin and core temperatures for cod were $1.5( \pm 0.8)$ and $1.4^{\circ} \mathrm{C}( \pm 0.7)$, respectively. Each fish recorded a minimum temperature of $0^{\circ} \mathrm{C}$ for both skin and core readings. No difference in the growth of TVC grown on PCA with or without $1 \% \mathrm{NaCl}$ was observed $(P>0.05)$, and therefore, only data obtained with $1 \% \mathrm{NaCl}$ are presented. TVCs for salmon increased from 1.1 and 2.7 to 5.1 and $5.7 \log _{10} \mathrm{CFU} / \mathrm{cm}^{2}$ and those for cod increased from 3.0 and 3.9 to 5.2 and $5.8 \log _{10}$ $\mathrm{CFU} / \mathrm{cm}^{2}$ on flesh and skin swab samples, respectively, over the 10-day storage period.

For salmon fillets, post-rigour 'stiffness', the term used to describe firmness, was the first attribute associated with a lack of freshness by the majority of panellists after 3 days and all by day 6. For whole fish, 'cloudy, dull, sunken' eyes and 'brown, shrivelled' gills are indicators of loss of freshness, with all panellists indicating the maximum score for the former at day 8 and for the 'brown shrivelled' gills at day 6 . With the exception of odour (maximum QI score after 10 days), none of the other attributes reached their maximum score over the course of the experiment. Post-rigour stiffness and odour were also the attributes associated with lack of freshness in cod fillets, and these attributes both achieved the maximum 
score of 1 and 2, respectively (from all panellists) by day 10 . The QDA for cooked salmon suggested that colour was the most important attribute in the early indication of spoilage with seven of the 10 panellists giving it a top score after 8 days and all by 10 days, whereas for cooked cod, odour was considered the most important attribute, achieving a maximum demerit score by day 10. In contrast, most of the panellists did not consider the taste of fish to be either 'strong, fishy, offensive and unpleasant' or 'dry or very dry' until day 10 . The other attributes had not reached the maximum demerit score by the end of the trial. Overall, the panel suggested that salmon was spoiled by day 10 and cod by day 8 .

Regression analysis suggested a strong relationship between the QIM scores and TVC for salmon flesh $\left(R^{2}=0.93\right)$ and skin swab $\left(R^{2}=0.95\right)$, with approximately 10 to 14 sensory units lost for each $1 \log _{10} \mathrm{CFU} / \mathrm{cm}^{2}$ increase in the bacterial count (Figures $1 \mathrm{~A}$ and $1 \mathrm{~B}$ ). The corresponding $R^{2}$ values for cod were 0.89 and 0.77 with a decrease of 12 to 15 sensory units per $1 \log _{10} \mathrm{CFU} / \mathrm{cm}^{2}$ increase in TVC (Figures $1 \mathrm{C}$ and 1D). Similar results were obtained for QDA scores versus time with $R^{2}$ values of 0.93 (salmon-flesh TVC), 0.94 (salmon-skin swab TVC) and 0.77 (cod-flesh TVC), although the $R^{2}$ value for cod QDA versus skin swab TVC at 0.6 suggested that the data were not as close to the fitted regression line (Figure 2). Regardless, approximately 11 to 16 sensory units were lost for each $1 \log _{10} \mathrm{CFU} / \mathrm{cm}^{2}$ increase in TVC.

Regression analysis (Figure 3) also suggested a strong relationship between time and the QIM scores for salmon $\left(R^{2}\right.$ $=0.96)$ and $\operatorname{cod}\left(R^{2}=0.98\right)$. The corresponding $R^{2}$ values for time versus QDA scores were 0.94 and 0.87 for salmon and cod, respectively (Figure 3 ).

After death, adenosine phosphate was immediately degraded to IMP and then more slowly to I and Hx. The IMP, I and Hx concentrations at each sampling time as well as the IMP/Hx ratio, $K_{1}$-value and $H$-value, for salmon and cod are shown in Tables 5 and 6 , respectively. On day 0 , the concentration of IMP in the salmon samples was $2.8 \mathrm{mg} / \mathrm{g}$, which decreased to $0.6 \mathrm{mg} / \mathrm{g}$ after 3 days before decreasing to $0.3 \mathrm{mg} / \mathrm{g}$ after 10 days. The initial $\mathrm{Hx}$ concentration was $1.0 \mathrm{mg} / \mathrm{g}$, which showed an increase to $1.5 \mathrm{mg} / \mathrm{g}$ after 10 days. The concentration of I remained relatively constant (3.2 to $3.9 \mathrm{mg} / \mathrm{g}$ ) throughout the trial. With the exception of $H$-values $\left(R^{2}=0.93\right)$, the relationship between time and IMP, I or $\mathrm{Hx}$ concentration or between time and IMP/Hx ratio and $K_{\text {-value }}$ was non-linear.

At time $t=0$, the concentration of IMP in cod samples was $8.3 \mathrm{mg} / 100 \mathrm{~g}$, which decreased to $0.5 \mathrm{mg} / 100 \mathrm{~g}$ by day 3 and thereafter remained at a residual concentration of approximately $1.0 \mathrm{mg} / 100 \mathrm{~g}$. The initial $\mathrm{Hx}$ concentration was $4.8 \mathrm{mg} / 100 \mathrm{~g}$, which increased to $6.7 \mathrm{mg} / 100 \mathrm{~g}$ after 2 days and remained at 6 to $8 \mathrm{mg} / 100 \mathrm{~g}$ thereafter. I concentrations decreased from $40.6 \mathrm{mg} / 100 \mathrm{~g}$ at time $\mathrm{t}=0$ to $22.3 \mathrm{mg} / 100 \mathrm{~g}$
(A)

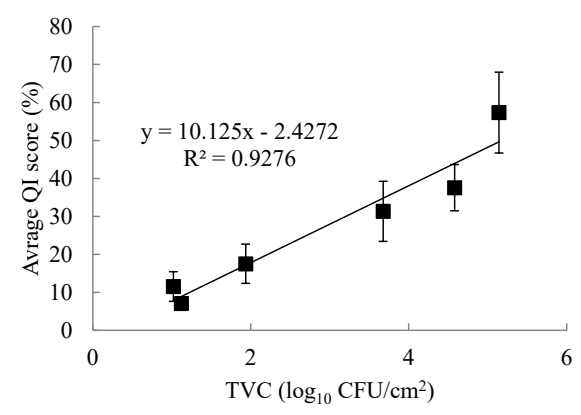

(B)

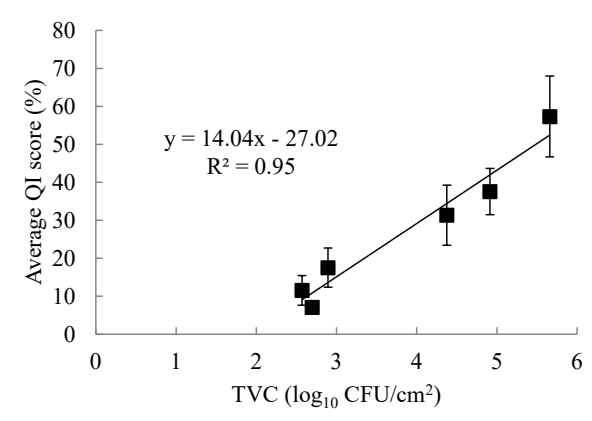

(C)

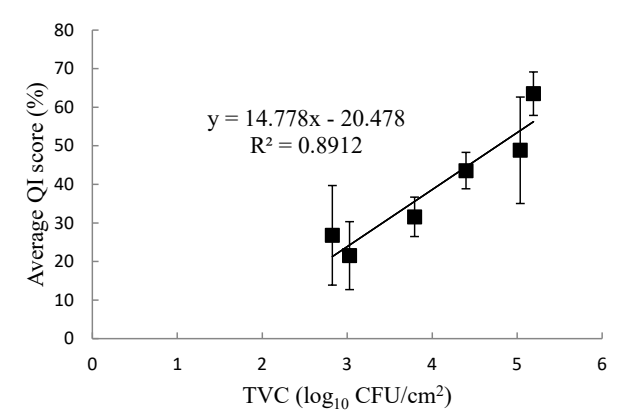

(D)

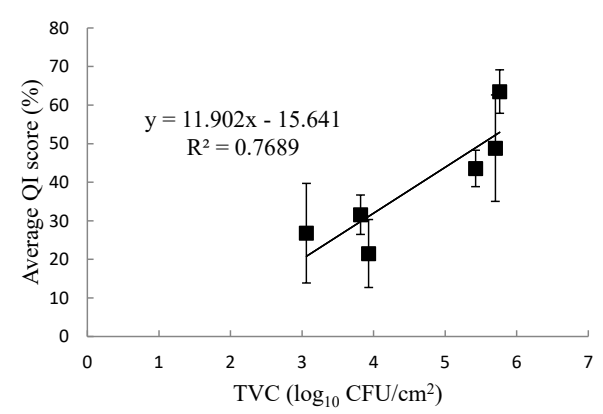

Figure 1. Relationship between the quality index (QI) score and the total viable count (TVC) for fresh salmon (Salmo salar) (A) flesh and (B) skin swabs and cod (Gadus morhua) (C) flesh and (D) skin swabs stored aerobically on ice in a chilled room at $2^{\circ} \mathrm{C}$ for 10 days. Each point corresponds to 24 data values. 
(A)

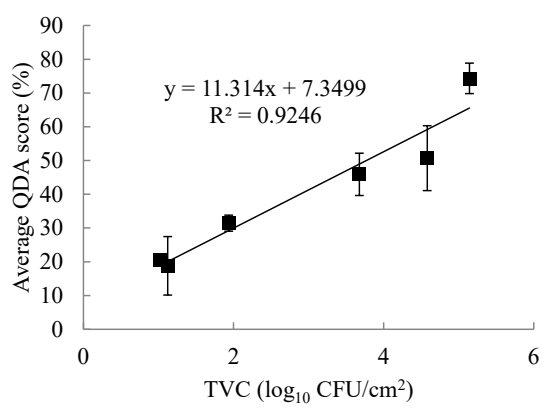

(B)

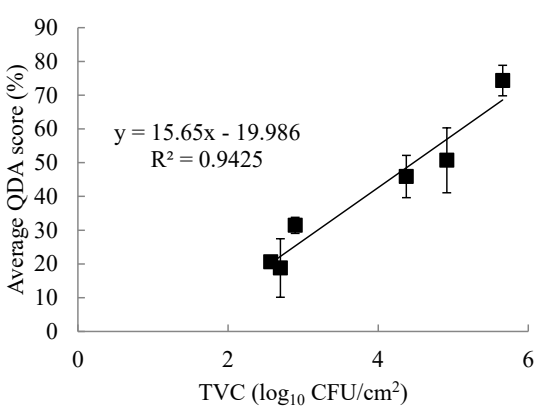

(C)

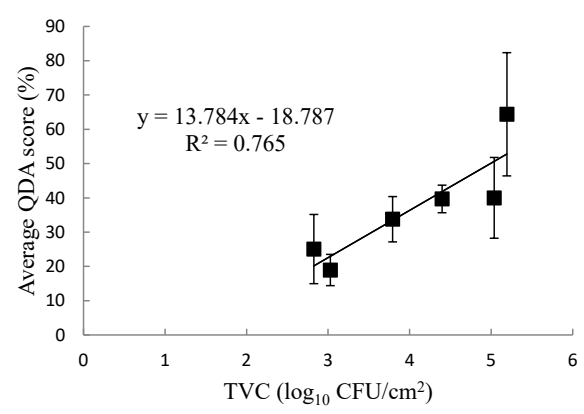

(D)

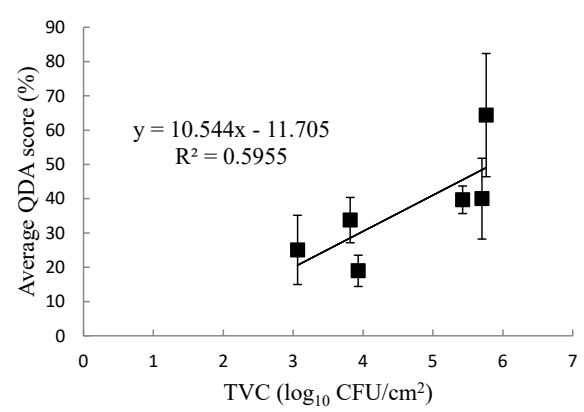

Figure 2. Relationship between the quantitative descriptive analysis (QDA) score and the total viable count (TVC) for fresh salmon

(Salmo salar) (A) flesh and (B) skin swabs and cod (Gadus morhua) (C) flesh and (D) skin swabs stored aerobically on ice in a chilled room at $2^{\circ} \mathrm{C}$ for 10 days. Each point corresponds to 24 data values.
(A)

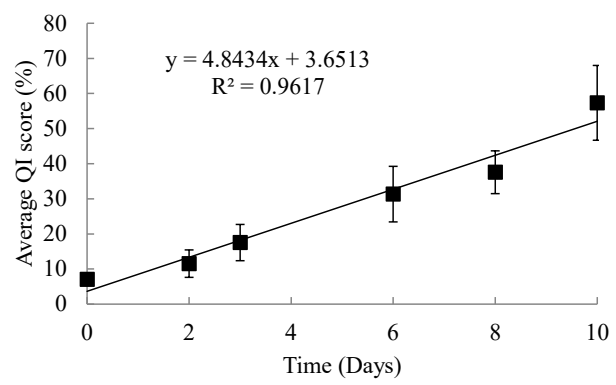

(B)

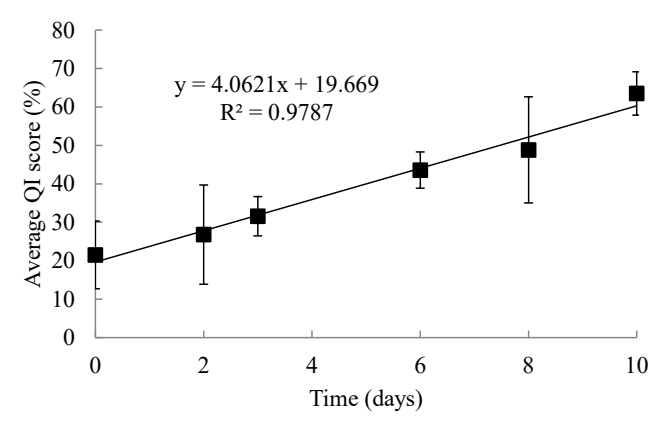

(C)

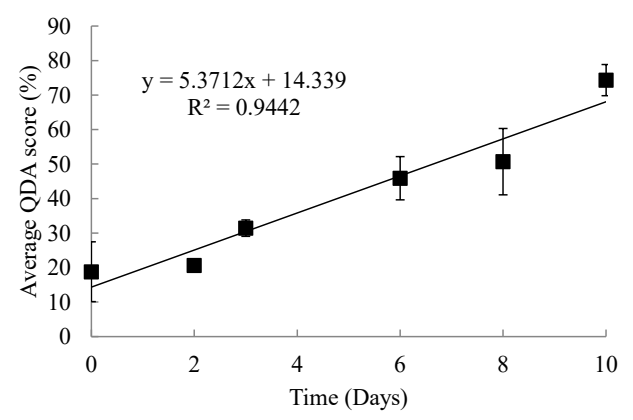

(D)

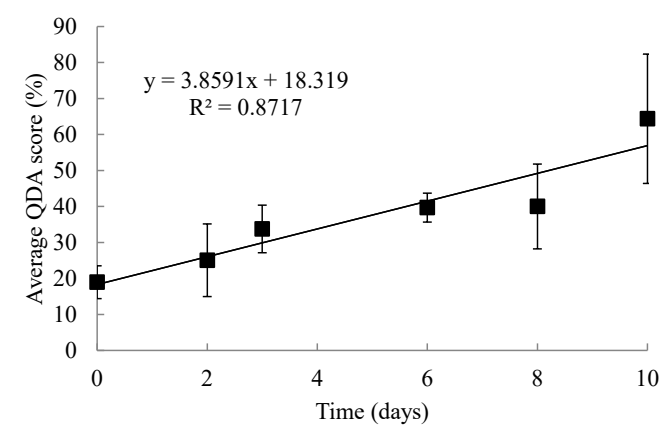

Figure 3. Relationship between the quality index (QI) score and time (days) for (A) salmon (Salmo salar) and (B) cod (Gadus morhua) and the relationship between quantitative descriptive analysis (QDA) score and time (days) for (C) salmon and (D) cod (Gadus morhua) stored aerobically on ice in a chilled room at $2^{\circ} \mathrm{C}$ for 10 days. Each point corresponds to 24 data values. 
Table 5. Inosine monophosphate (IMP), inosine (I) and hypoxanthine (Hx) concentrations together with IMP/Hx ratio, $K_{-}$-value and $H$-value for salmon (Salmo salar) stored aerobically at $2^{\circ} \mathrm{C}$ for 10 days

\begin{tabular}{|c|c|c|c|c|c|c|}
\hline Time (d) & IMP (mg/g) & I (mg/g) & $\mathrm{Hx}(\mathrm{mg} / \mathrm{g})$ & IMP/Hx ratio & $\mathrm{K}_{1}$-value (\%) & $\mathrm{H}$-value $(\% \mathrm{Hx})$ \\
\hline 0 & 2.8 & 3.6 & 1.0 & 2.8 & 82.2 & 13.5 \\
\hline 2 & 1.9 & 3.9 & 1.2 & 1.6 & 72.9 & 17.1 \\
\hline 3 & 0.6 & 3.8 & 1.2 & 0.5 & 89.3 & 21.4 \\
\hline 6 & 0.7 & 3.2 & 1.3 & 0.5 & 86.5 & 25.0 \\
\hline 8 & 0.6 & 3.2 & 1.3 & 0.5 & 88.2 & 25.5 \\
\hline 10 & 0.3 & 3.5 & 1.5 & 0.2 & 94.3 & 28.3 \\
\hline$R^{2}$ & 0.71 & 0.38 & 0.69 & 0.69 & 0.51 & 0.93 \\
\hline
\end{tabular}

$K_{1}$-value $=I+H x /(I M P+I+H x) \times 100 . H$-value $=H x /(I M P+I+H x) \times 100$.

Table 6. Inosine monophosphate (IMP), inosine (I) and hypoxanthine $(\mathrm{Hx})$ concentrations together with IMP/Hx ratio, $K_{1}-$ value and $H$-value for cod (Gadus morhua) stored aerobically at $2^{\circ} \mathrm{C}$ for 10 days

\begin{tabular}{|c|c|c|c|c|c|c|}
\hline Time (d) & IMP (mg/100 g) & $\mathrm{I}(\mathrm{mg} / 100 \mathrm{~g})$ & $\mathrm{Hx}(\mathrm{mg} / 100 \mathrm{~g})$ & IMP/Hx ratio & $\mathbf{K}_{1}$-value & $\mathrm{H}$-value (\%Hx) \\
\hline 0 & 8.3 & 40.6 & 4.8 & 1.73 & 84.5 & 8.9 \\
\hline 2 & 4.3 & 35.6 & 6.7 & 0.64 & 90.8 & 14.4 \\
\hline 3 & 0.5 & 34.1 & 6.6 & 0.07 & 98.8 & 16.0 \\
\hline 6 & 1.1 & 34.1 & 6.0 & 0.18 & 97.3 & 14.6 \\
\hline 8 & 0.6 & 27.3 & 7.4 & 0.08 & 98.3 & 21.0 \\
\hline 10 & 1.0 & 22.3 & 7.8 & 0.13 & 96.8 & 22.1 \\
\hline$R^{2}$ & 0.57 & 0.91 & 0.65 & 0.53 & 0.53 & 0.84 \\
\hline
\end{tabular}

$K_{1}$-value $=I+H x /(I M P+I+H x) \times 100 ; H$-value $=H x /(I M P+I+H x) \times 100$.

by day 10 . There was a linear relationship between time and I concentration $\left(R^{2}=0.91\right)$ and $H$-value $\left(R^{2}=0.84\right)$, but the relationship of time with IMP $\left(R^{2}=0.57\right), \mathrm{Hx}\left(R^{2}=0.65\right)$, IMP/ $\mathrm{Hx}$ ratio $\left(R^{2}=0.53\right)$ and $K_{1}$-value $\left(R^{2}=0.53\right)$ was less well defined.

\section{Discussion}

Initial TVCs ranged from 1.1 to $3.9 \log _{10} \mathrm{CFU} / \mathrm{cm}^{2}$, suggesting the fish were from clean water (Gram and Huss, 1996; Gram; 1992) and of good microbiological quality (Schubring, 2003; Briones et al., 2010; Li et al., 2017). By the end of sensory shelf life for each fish (10 days for salmon and 8 days for cod), the $T_{V} C_{m}$ ranged from 5.1 to $5.8 \log _{10} \mathrm{CFU} / \mathrm{cm}^{2}$. This is in agreement with Robson et al. (2007), who found seafood spoiled when the bacterial count reached 5 to $6 \log _{10} \mathrm{CFU} /$ $\mathrm{cm}^{2}$.

The QIM developed for salmon and cod provided a good description of the sensory changes that occurred during aerobic chilled storage, and the linear relationship between QIM scores and both TVC and time suggested that this scheme could be used to assess fish freshness. This was complemented by the QDA for cooked fish. Other studies have also reported a linear relationship between QIM score and time for salmon (Sveinsdottir et al., 2002, 2003), blackspot seabream (Sant'Ana et al., 2011) and rainbow trout (Diler and Genç, 2018).

In this study, the IMP concentration decreased in the salmon (2.8 to $0.3 \mathrm{mg} / \mathrm{g}$ ) and cod ( 8.3 to $1.0 \mathrm{mg} / 100 \mathrm{~g}$ ) over the 10 days aerobic storage at $2^{\circ} \mathrm{C}$. I levels did not change for salmon but decreased in cod from 40.6 to $22.3 \mathrm{mg} / 100 \mathrm{~g}$. In contrast, only a minor increase was observed in the $\mathrm{Hx}$ concentration for both salmon $(1.0$ to $1.5 \mathrm{mg} / \mathrm{g})$ and cod $(4.8$ to $7.8 \mathrm{mg} / 100 \mathrm{~g}$ ). Similar data from other fish studies are limited and that which are available focus on $\mathrm{Hx}$. Burns et al. (1985) found initial $\mathrm{Hx}$ concentrations of 0.12 and $0.15 \mathrm{mg} / \mathrm{g}$ in mackerel and cod, respectively. Whittle et al. (1990) reported that $\mathrm{Hx}$ levels increased from 2.4 to $8.8 \mathrm{mg} / 100 \mathrm{~g}$ in cod stored on ice for 10 days. Other studies obtained increases from 3.3 to $16.6 \mathrm{mg} / 100 \mathrm{~g}$ in striped bass fillets stored at $4^{\circ} \mathrm{C}$ for a similar time period (Karahadian et al., 1997) and from 0.09 to $0.41 \mathrm{mg} / \mathrm{g}$ in salmon stored at $1^{\circ} \mathrm{C}$ for 20 days (Sallam, 2007). Karahadian et al. (1997) proposed that the loss of freshness should be expressed as an IMP/Hx ratio, $K_{1}$-value [I $+\mathrm{Hx} /(\mathrm{IMP}$ $+1+\mathrm{Hx}) \times 100]$ or $H$-value [Hx/(IMP $+1+\mathrm{Hx}) \times 100]$ rather than monitoring the concentration of ATP derivatives. They argued that these ratios are a better indicator of freshness as they take into account the concentrations of all the ATP derivatives. In the current study, the IMP/Hx ratio, $K_{1}$-value 
and $\mathrm{H}$-value for salmon changed from initial values of 2.8 , $82.2 \%$ and $13.5 \%$ to $0.2,94.3 \%$ and $28.3 \%$, respectively. The corresponding values for cod were $1.73,84.5 \%$ and $8.9 \%$ at time $t=0$, respectively, changing to $0.13,96.8 \%$ and $22.1 \%$ after 10 days. Karahadian et al. (1997) reported a $K_{1}$-value of $37.8 \%$ at time $t=0$ for striped bass, which did not exceed $90 \%$ until day 9 .

The pattern of increase in $\mathrm{H}$-value occurred linearly in salmon and cod for both TVC and time, but the relationships between IMP/Hx ratio and $K_{1}$-values were non-linear. Other studies on the optimum ATP derivative/ratio for monitoring fish freshness are contradictory (Bremner, 1985; Murata and Sakaguchi, 1988; Whittle et al., 1990; Sallam, 2007). This was not unexpected as nucleotide degradation rates depend on a range of factors including fish maturity, muscle type, stress during capture and storage conditions (Luong et al., 1992; Huss, 1995; Erikson et al., 1997).

\section{Conclusions}

QIM and QDA schemes developed in this study may be used as a rapid sensory-based tool for assessing the freshness of salmon and cod. Moreover, 'cloudy, dull and sunken' eyes and brown shrivelled gills provide early indicators of loss of freshness of whole fish. The $H$-value may be a suitable ATP derivative ratio for assessing salmon and cod freshness, but given the conflicting reports in the literature, further studies are needed to confirm this finding.

\section{Acknowledgements}

Funding for this project was provided by the Food Institutional Research Measure, project number 13F458, administered by the Department of Agriculture, Food and the Marine.

\section{References}

Alfaro, B., Hernandez, I., Balino-Zuazo, L. and Barranco, A. 2013. Quality changes of Atlantic horse mackerel fillets (Trachurus trachurus) packed in a modified atmosphere at different storage temperatures. Journal of the Science of Food and Agriculture 93: 2179-2187.

Anacleto, P., Teixeira, B., Marques, P., Pedro, S., Nunes, M.L. and Marques, A. 2011. Shelf-life of cooked edible crab (Cancer pagurus) stored under refrigerated conditions. LWT - Food Science and Technology 44: 1376-1382.

Andrade, A., Nunes, M.L., and Batista, I. 1997. Freshness quality grading of small pelagic species by sensory analysis. In: "Methods to Determine the Freshness of Fish in Research and Industry".
Proceedings of the Final Meeting of the Concerted Action "Evaluation of Fish Freshness" AIR3CT94 2283, Nantes Conference, November 12-14, 1997, pages 333-338.

Beauchat, L.R. 1973. Hypoxanthine measurement in assessing freshness of chilled channel catfish (Ictalurus punctatus). Journal of Agriculture and Food Chemistry 21: 453-455.

Bonilla, A.C., Sveinsdottir, K. and Martinsdottir, E. 2007. Development of Quality Index Method (QIM) scheme for fresh cod (Gadus morhua) fillets and application in shelf life study. Food Control 18: 352-358.

Bremner, H.A. 1985. A convenient, easy to use system for estimating the quality of chilled seafoods. Fish Processing Bulletin 7: 59-70.

Bremner, H.A., Olley, J., Statham, J.A. and Vail, A.M.A. 1988. Nucleotide catabolism: influence on the storage life of tropical species of fish from the North West Shelf of Australia. Journal of Food Science 53: 6-11.

Briones, L.S., Reyes, J.E., Tabilo-Munizaga, G.E. and Pérez-Won, M.O. 2010. Microbial shelf-life extension of chilled Coho salmon (Oncorhynchus kisutch) and abalone (Haliotis rufescens) by high hydrostatic pressure treatment. Food Control 21: 1530-1535.

Burns, G.B., Ke, P.J. and Irvine, B.B. 1985. Objective procedure for fish freshness evaluation based on nucleotide changes using a HPLC system. Canadian Technical Report of Fisheries and Aquatic Sciences 1373: 1-39.

Chen, H.-C., Huang, Y.-R., Hsu, H.-H., Lin, C.-S., Chen, W.-C., Lin, C.-M. and Tsai, Y.-H. 2010. Determination of histamine and biogenic amines in fish cubes (Tetrapturus angustirostris) implicated in a food-borne poisoning. Food Control 21: 13-18.

Diler, A. and Genç, İ.Y. 2018. A practical quality index method (QIM) developed for aquacultured rainbow trout (Oncorhynchus mykiss). International Journal of Food Properties 21: 857-866.

Dingle, J.R. and Hines, J.A. 1971. Degradation of inosine 5'-monophosphate in the skeletal muscle of several North Atlantic fishes. Journal of the Fisheries Research Board of Canada 28: 1125-1131.

Ehira, S. and Uchiyama, H. 1974. Freshness-lowering rates of cod and sea bream viewed from changes in bacterial count, total volatile base- and trimethylamine-nitrogen, and ATP related compounds. Bulletin of the Japanese Society of Fisheries Science 40 : 479-487.

Erikson, U., Beyer, A.R. and Sigholt, T. 1997. Muscle high-energy phosphates and stress affect K-values during ice storage of Atlantic salmon (Salmo salar). Journal of Food Science 62: 43-47.

Ghanbari, M., Jami, M., Domig, K.J. and Kneifel, W. 2013. Seafood biopreservation by lactic acid bacteria - A review. LWT - Food Science and Technology 54: 315-324.

Gram, L. 1992. Spoilage of three Senegalese fish species stored in ice at ambient temperature. In: "Seafood Science and Technology”, (ed. E.C. Bligh). Fishing News Books, Blackwell, Oxford, pages 225-239.

Gram, L. and Dalgaard, P. 2002. Fish spoilage bacteria - problems and solutions. Current Opinion in Biotechnology 13: 262-266.

Gram, L. and Huss, H.H. 1996. Microbiological spoilage of fish and 
fish products. International Journal of Food Microbiology 33: 121-137.

Huss, H.H. 1995. "Quality and Quality Changes in Fresh Fish", FAO Fisheries Technical Paper - 348, Food and Agriculture Organization of the United Nations, Rome. Available online at: http://www. fao.org/3/V7180E/v7180e01.htm.

Jahns, F.D. and Rand, A.G. 1977. Enzyme methods to assess marine food quality. In: "Enzymes in Food and Beverage Processing", (eds: R.L. Orly and A.J. St. Angelo), American Chemical Society, Washington DC, Symposium Series 47, pages 266-278.

Jones, N.R., Murray, J., Livingston, E.I. and Murray, C.K. 1964. Rapid estimations of hypoxanthine concentrations as indices of the freshness of chill-stored fish. Journal of the Science of Food and Agriculture 15: 763-774.

Jónsdóttir, S. 1992. Quality index method and TQM-system. In: "Quality Issues in the Fish Industry", (eds. Olafsson, R., and Ingthorsson, A.H.), Reykjavik, Iceland Proceedings from the COMETT conference course: quality issues in the fish. industry, European cooperation, September 1992, pages 81-94..

Karahadian, C., Brannan, R.G. and Heath, J.L. 1997. Electron beam irradiation, oxygen, and temperature effects on nucleotide degradation in stored aquaculture hybrid striped bass fillets. Journal of Food Quality 20: 157-169.

Kassemsarn, B., Perez, B.S., Murray, J. and Jones, N.R. 1963. Nucleotide degradation in the muscle of iced haddock (Gadus aeglefinus), lemon sole (Pleuronectes microcephalus), and plaice (Pleuronectes platessa). Journal of Food Science 28: 28-37.

Kulawik, P., Ozogul, F., Glew, R. and Ozogul, Y. 2013. Significance of antioxidants for seafood safety and human health. Journal of Agriculture and Food Chemistry 61: 475-491.

Li, X., Chen, Y., Cai, L., Xu, Y., Yi, S., Zhu, W., Mi, H., Li, J. and Lin, H. 2017. Freshness assessment of turbot (Scophthalmus maximus) by Quality Index Method (QIM), biochemical, and proteomic methods. LWT - Food Science and Technology 78: 172-180.

Luong, J.H.T., Male, K.B., Masson, C. and Nguyen, A.L. 1992. Hypoxanthine ratio determination in fish extract using capillary electrophoresis and immobilized enzymes. Journal of Food Science 57: 77-81.

Luten, J.B., Oehlenschläger, J. and Ólafsdóttir, G. 2000. "Quality of Fish from Catch to Consumer", Wageningen Academic Publishers, Wageningen, The Netherlands, pages 265-283.

Martinsdóttir, E., Sveinsdóttir, K., Luten, J., Schelvis-Smit, R. and Hyldig, G. 2001. "Reference Manual for the Fish Sector: Sensory
Evaluation of Fish Freshness. QIM Eurofish, In: "Quality of Fish from Catch to Consumer", (eds: J.B.Luten, J. Oehlenschläger \& G. Ólafsdóttir), Wageningen Academic Publishers, Wageningen, The Netherlands, 265-272.

Mørkøre, T., Rødbotten, M., Vogt, G., Fjæra, S.O., Kristiansen, I.Ø. and Manseth, E. 2010. Relevance of season and nucleotide catabolism on changes in fillet quality during chilled storage of raw Atlantic salmon (Salmo salar L.). Food Chemistry 119: 1417-1425.

Murata, M. and Sakaguchi, M. 1988. Changes in free amino acids and adenine nucleotides in boiled muscle extracts of yellowtail (Seriola quinqueradiata) stored in ice. Journal of Agricultural and Food Chemistry 36: 595-599.

Robson, A.A., Kelly, M.S. and Latchford, J.W. 2007. Effect of temperature on the spoilage rate of whole, unprocessed crabs: Carcinus maenas, Necora puber and Cancer pagurus. Food Microbiology 24: 419-424.

Sallam, K.I. 2007. Chemical, sensory and shelf life evaluation of sliced salmon treated with salts of organic acids. Food Chemistry 101: 592-600.

Sant'ana, L.S., Soares, S. and Vaz-Pires, P. 2011. Development of a quality index method (QIM) sensory scheme and study of shelflife of ice-stored blackspot seabream (Pagellus bogaraveo). LWT - Food Science and Technology 44: 2253-2259.

Schirmer, B.C., Heiberg, R., Eie, T., Møretrø, T., Maugesten, T., Carlehøg, M. and Langsrud, S. 2009. A novel packaging method with a dissolving $\mathrm{CO}_{2}$ headspace combined with organic acids prolongs the shelf life of fresh salmon. International Journal of Food Microbiology 133: 154-160.

Schubring, R. 2003. Colour measurement on skin during storage of wet and frozen fish. In: "Quality of Fish from Catch to Consumer", (eds: J.B.Luten, J. Oehlenschläger \& G. Ólafsdóttir), Wageningen Academic Publishers, Wageningen, The Netherlands, 251-263.

Sveinsdottir, K., Hyldig, G., Martinsdottir, E. and Jørgensen, B. 2003. Quality index method (qim) scheme developed for farmed atlantic salmon (Salmo salar). Food Quality and Preference 14: 237-245.

Sveinsdottir, K., Martinsdottir, E., Hyldig, G., Jørgensen, B. and Kristbergsson, K. 2002. Application of Quality Index Method (QIM) scheme in shelf-life study of farmed Atlantic salmon (Salmo salar). Journal of Food Science 67: 1570-1579.

Whittle, K., Hardy, R. and Hobbs, G. 1990. Chilled fish and fishery products. In: "Chilled Foods. The State of the Art", (ed. T. Gormley.), Elsevier, Amsterdam, The Netherlands, 87-117. 